\title{
Floating kidney
}

\author{
Akshay Sood, ${ }^{1,2}$ Craig Rogers ${ }^{1,2}$
}

${ }^{1}$ Vattikuti Urology Institute, Henry Ford Hospital, Detroit, Michigan, USA

${ }^{2}$ VCORE | Vattikuti Urology Institute, Henry Ford Hospital, Detroit, Michigan, USA

Correspondence to Dr Akshay Sood, asood1@hfhs.org

Accepted 6 April 2018

\section{DESCRIPTION}

A 28-year-old, healthy woman with a history of abdominal pain of almost 6 years came to see us in our clinic after having seen several physicians at several different hospitals over the years. The chief presenting complaint had remained consistent-it was intermittent right abdominal pain that tended to exacerbate in the upright position and improve in the supine position. The change in position was also associated with a feeling of 'a ball rolling' inside of her. There were no other symptoms. Of note, during enquiry into her obstetrical history, the patient recalled that her pain always seemed to be less during pregnancy, especially in the later trimesters.

Physical exam revealed a thin woman with no acute findings on abdominal exam. Prior lab testing and imaging work-ups, including computed abdominal tomography, had been normal.

Given the nature of her complaints, we performed intravenous pyelography-a simplistic imaging test that lends information about the dynamic anatomy of a patient. A $6 \mathrm{~cm}$ craniocaudal migration of the right kidney was noted between the supine and upright postures (figure 1). A diagnosis of nephroptosis was made.

Nephroptosis or floating kidney is a condition in which the kidney descends more than two vertebral bodies or $>5 \mathrm{~cm}$ during a position change from supine to upright. ${ }^{12}$ It is a condition that typically afflicts thin women. It is estimated that $20 \%$ of women on dynamic imaging tests have evidence of nephroptosis; however, the majority are asymptomatic. ${ }^{3}$ An absence of

\section{Learning points}

- Nephroptosis is an important differential diagnosis in young, thin women with unexplained abdominal pain following exclusion of common aetiologies.

- It can be readily diagnosed with simple dynamic imaging tests.

Treatment is nephropexy and is highly effective.

perirenal fat has been hypothesised as the reason for the condition.

Symptomatic nephroptosis, although uncommon, has very specific signs and symptoms, as in this case. The patient consistently reported two symptoms-abdominal pain that improved with lying down and pregnancy (gravid uterus providing support to the kidney) and a feeling of a mass rolling inside of her. A dynamic imaging test, for example, an upright-supine intravenous pyelogram, nuclear scan or Doppler ultrasonogram, rather than a static one (computed abdominal tomogram) is helpful in finalising the diagnosis. Nephropexy is the treatment of choice once the diagnosis is established-the preferred approach nowadays is laparoscopic.

Our patient was taken to the operating room for robot-assisted laparoscopic nephropexy. She was discharged home on postoperative day 1. At the 4-week follow-up, she reported a remarkable improvement in her symptoms. She no longer felt any pain. The patient was grateful that her symptoms had finally abated after 6 years.
To cite: Sood A, Rogers C. BMJ Case Rep Published Online First: [please include Day Month Year]. doi:10.1136/bcr-2018224921
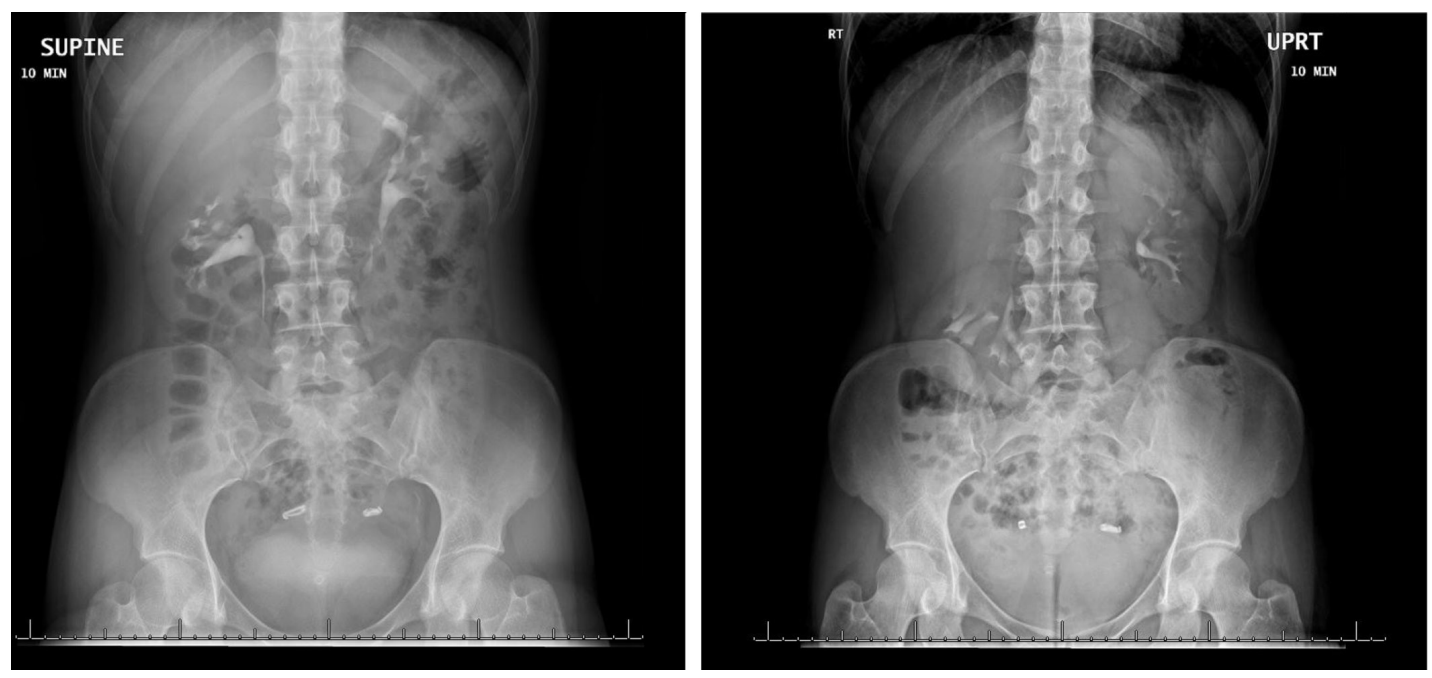

Figure 1 Intravenous pyelography performed in supine and upright positions demonstrating $>5 \mathrm{~cm}$ craniocaudal migration of the right kidney that is pathognomonic of renal ptosis. 
Contributors Conception and design, acquisition of data, or analysis and interpretation of data: AS, CR. Drafting the article or revising it critically for important intellectual content: $A S, C R$. Final approval of the version published: $A S, C R$.

Funding This research received no specific grant from any funding agency in the public, commercial or not-for-profit sectors.

Competing interests None declared.

Patient consent Obtained.

Provenance and peer review Not commissioned; externally peer reviewed. (c) BMJ Publishing Group Ltd (unless otherwise stated in the text of the article) 2018. All rights reserved. No commercial use is permitted unless otherwise expressly granted.

\section{REFERENCES}

1 McDougall EM, Afane JS, Dunn MD, et al. Laparoscopic nephropexy: long-term followup-Washington University experience. J Endourol 2000;14:247-50.

2 Hoenig DM, Hemal AK, Shalhav AL, et al. Nephroptosis: a "disparaged" condition revisited. Urology 1999;54:590-6.

3 Braasch WF, Greene LF, Goyanna R. Renal ptosis and its treatment. J Am Med Assoc 1948;138:399-403.

Copyright 2018 BMJ Publishing Group. All rights reserved. For permission to reuse any of this content visit http://group.bmj.com/group/rights-licensing/permissions.

BMJ Case Report Fellows may re-use this article for personal use and teaching without any further permission.

Become a Fellow of BMJ Case Reports today and you can:

- Submit as many cases as you like

- Enjoy fast sympathetic peer review and rapid publication of accepted articles

- Access all the published articles

- Re-use any of the published material for personal use and teaching without further permission

For information on Institutional Fellowships contact consortiasales@bmjgroup.com

Visit casereports.bmj.com for more articles like this and to become a Fellow 